\title{
Effects of Language Intervention based on Augmented Reality for Verbal Expression in Children with Expressive Language Delay
}

\author{
MyeongJin Lee ${ }^{a}$, BoMyung Hwang ${ }^{\mathrm{b}}$ \\ ${ }^{a}$ Department of Speech-Language Pathology, Graduate School of Honam University, Gwangju, Korea \\ ${ }^{b}$ Department of Speech-Language Pathology, School of Health Science, Honam University, Gwangju, Korea
}

Correspondence: BoMyung Hwang, PhD Department of Speech-Language Pathology, School of Health Science, Honam University, 417 Eodeung-daero, Gwangsan-gu, Gwangju 62399, Korea

Tel: +82-62-940-5542

Fax: +82-62-940-5046

E-mail: slphwang@honam.ac.kr

Received: April 20, 2018

Revised: May 25, 2018

Accepted: June 10, 2018

This work was supported by the Ministy of Education of the Republic of Korea and the National Research Foundation of Korea (No. NRF2015S1A5B6037281).

This work is based on the master's thesis of the first author (2017).
Objectives: When learning verbs that represent the movement, this study hypothesized that language intervention based on augmented reality (AR) can be more effective than picture cards and examined what effect AR has on the improving verbal expression of children with delayed expressive-language development. The study developed an application using AR that mixed reality with virtual reality in an application for children with expressive language delay. Methods: The subjects were three children (mean chronological age, 3.6 years) whose expressive language abilities were delayed more than 6 months beyond than their chronological age. Eighty-four goal verbs were presented using AR in a multiple baseline design, along with face-to-face training to improve verbal expressions. Results: Children with expessive language delay showed increased accuracy in verb expression through language intervention based on AR. Additionally, the children generalized their improvements by expressing goal verbs even when they were presented as picture cards. Conclusion: This study shows that language intervention based on AR is effective for improving the verbal expression of children with expressive language delay. Utilizing to represent the movement and status of verbs has positive effects on verbal expression.

Keywords: Language intervention, Augmented reality, Expressive language delay
2017년 1월 스위스 다보스에서 개최된 세계경제포럼 연차회의에 서는 4차 산업혁명에 대하여 ‘디지털 혁명에 기반하여 물리적, 디지 털, 생물학적 공간의 경계가 희석되는 기술융합의 시대’로 정의하 였다(https://www.weforum.org/events/world-economic-forumannual-meeting-2017). 경계의 희석 혹은 기술융합이라는 용어는 이제 우리의 일상에서 그리 어렵지 않게 접하게 되었다. 디지털 기 기의 성능은 하루가 다르게 발전하고 대중화되고 있으며 생활환경 을 변화시키고 있다. 이는 교육과 치료현장의 변화로도 연결될 것이 며 이미 다양한 학문 분야로 확산 중이다.

증강현실(augmented reality, AR)이란 현실과 가상현실(virtual reality, VR)의 중간에 위치하는 기술로, 사용자의 환경에 가상의 정보를 더해줌으로써 실제감을 향상시키는 기술이다(Jang \& Kye, 2007). 이는 가상의 사물이나 정보를 합성하여 마치 존재하는 사물
처럼 보이도록 하는 컴퓨터그래픽기법으로(Billinghurst \& Kato, 2002), 즉 가상현실에서의 대상은 '내가 가상의 다른 세계로 가서 보는 것'이라면, 증강현실에서의 대상은 '내가 있는 현실로 소환되 어 보여지는 것'이라 할 수 있다(Shim, Cho, \& Kim, 2017). 가상현 실은 모든 장면이 가상으로 표현되므로 실제 환경의 감각으로부터 는 차단되지만 증강현실에서는 실제 환경을 카메라나 모니터로 볼 수 있으므로 중첩된 가상의 정보를 제공받게 되어 실제 환경이 반 영된 가상현실이 만들어지는 것이다(Lee, 2011). 최근에는 이러한 가상현실과 증강현실의 기술 발전을 통하여 교육콘텐츠 개발이 새 로운 방향을 맞이하고 있다. 과학, 역사, 패션 등 다양한 분야에서 증강현실을 활용한 교육콘텐츠를 제작하고 있으며 무료로 다운받 아 손쉽게 활용할 수 있는 'Aurasma'와 같은 애플리케이션도 등장 하였다. 증강현실을 통한 학습은 아동의 감각적 몰입 유발 및 능동 
적 반응 유도에 효과적이므로 학습 흥미를 높일 수 있으며(Bae, Park, Kim, \& Kwon, 2014; Ryu, Jo, Heo, Kim, \& Kye, 2006), 최근에는 특 수교육과 언어치료 분야에 증강현실을 적용한 연구들도 보고되고 있다(Kim \& Kwon, 2017).

생활연령이 증가함에 따라 이해하고 표현할 수 있는 어휘가 많아 지면서 아동들은 의도한 바를 나타내기 위하여 어휘를 조합하고 다양한 의미관계를 표현하게 된다. 어휘능력은 언어능력뿐 아니라 학습의 기초능력이지만(Kim et al., 2009), 환경적 요인 혹은 아동 개인의 역량 등에 따라 어휘발달에 양적·질적 차이가 발생할 수 있 다(Weizman \& Snow, 2001). 언어발달에 어려움을 겪고 있는 아동 들의 경우 표현어휘수가 부족하며 어휘 습득 속도 또한 느린 경향 이 있다(Nash \& Donaldson, 2005). 어휘 습득 시 아동은 물리적 세 계에 대한 지각을 통하여 사물을 이해하고 그 사물을 지칭하는 어 휘도 이해하게 된다. 사물의 명칭에 해당하는 명사는 물리적 세계 에서 명백히 드러나는 데 반해 동사는 그렇지 않기 때문에(Genter, 1982), 대부분의 언어 문화권에서는 초기 어휘 습득 시 명사 편향 성을 보인다(Waxman \& Lidz, 2006). 20-50개 낱말을 표현하는 아 동의 어휘를 품사별로 살펴보면 명사는 $45 \%$ 에 달하지만, 동사는 $3 \%$ 정도라고 한다(Caselli et al., 1995). 대부분의 언어에서 아동들 은 동사에 비하여 명사를 더 쉽게 습득하는데 이에 대하여 Tomasello (1992)는 명사는 참조하는 대상이 매우 구체적이지만 동사는 전체 행동이나 상태의 변화 중 어떤 부분이 해당 낱말이 참조하는 부분인지 인식하기 쉽지 않기 때문이라고 설명하였다. Tomasello 와 Kruger (1992)는 1-2세 아동에게 구체적 명시성을 달리한 문맥 을 제공하였을 때 애매한 행동 문맥에서보다 구체적인 행동 문맥에 서 아동들이 동사를 더 많이 학습한다고 하였다. 즉 동사는 사물과 의 관계를 나타내므로 실물이나 그림카드를 제시하는 것과 함께 행위의 움직임을 볼 수 있어야 습득이 용이해진다. 그러나 어휘 습 득 및 언어발달에 어려움을 겪고 있는 아동들의 경우 구체적인 참 조 대상이 있는 명사 학습에도 어려움을 보이며 참조물과의 관계 를 나타내는 동사 학습에는 더욱 많은 어려움을 보일 수 있다.

동사 학습은 언어치료실과 같은 제한된 공간 안에서 동작을 통 하여 학습하기에도 다소 한계가 있으며 그림카드를 이용하여 지도 하기에는 행동이나 상태의 변화를 나타내기가 쉽지 않다. 따라서 본 연구자들은 현실세계라는 배경하에서 역동적 움직임을 보여줄 수 있는 증강현실을 활용한다면 동사 학습에 매우 긍정적인 효과 를 보일 것이라는 가설을 세웠다. Kang, Park, Song, Kim과 Shin (2015)은 조음음운장애검사 시 증강현실을 활용한 시스템을 개발 하였고 특수교육 분야에서 증강현실을 교육에 활용한 몇몇 시도가 있었으나 표현언어발달이 지연된 아동들을 대상으로 동사를 지도
하기 위하여 증강현실을 적용한 연구는 거의 없는 실정이다. 이에 본 연구는 현실세계에 가상의 정보를 더해주는 증강현실을 동사 어휘 지도에 활용하여 표현언어발달지연 아동의 동사 표현에 미치 는 효과를 살펴보고자 하였다.

\section{연구방법}

\section{연구대상}

연구대상 선정을 위하여 광주광역시 지역 인터넷 육아카페에 연 구목적과 방법 및 절차 등에 대한 내용을 공고하였다. 이에 관심을 가지는 주 양육자들을 대상으로 자발적인 연구참여 동의를 확인 한 후 아래 기준에 해당하는 아동들을 선별하였다. (1) 생활연령이 만 3 세 이상 4 세 미만인 아동, (2) 시각, 청각 등의 감각 이상 및 신경 학적 이상이 없는 아동, (3) 신체 및 운동발달에 이상이 없는 아동, (4) 부모 보고에서 수용언어에 비하여 표현언어능력이 떨어지는 아 동, (5) 취학전 아동의 수용언어 및 표현언어 발달척도(Preschool Receptive-Expressive Language Scale, PRES; Kim, Sung, \& Lee, 2003) 검사 결과, 생활연령에 비하여 표현언어연령이 6개월 이상 지 연된 아동, (6) 언어치료를 받은 경험이 없는 아동이었다.

연구대상에게 PRES를 실시한 결과, 자신의 생활연령과 비교하 여 수용언어연령은 1-2개월 정도 낮게 나타났으나, 표현언어연령이 6개월 이상 낮게 산출된 아동들이었다. 아동 $\mathrm{A}$ 는 부끄럼을 많이 타 고 소극적이지만 사물에 대한 관심은 많은 편이며 '행위자-대상-행 위' 의미관계를 이해하고 지시 따르기가 가능하였다. 그러나 아직 '위', '안', '밖'과 같은 위치 부사어를 이해하지 못하며 또래에 비하 여 발화 명료도가 낮은 편이었다. 아동 B는 ‘어디', '무엇' '누가'와같 은 의문사 질문에 적절하게 반응하지 못하였으며, '밤/낮'에 대한 이해에 어려움을 보였다. 반의어 사용에도 어려움을 보이지만 '행 위자-대상-행위' 의미관계를 이해하고 지시 따르기가 가능하였다. 아동 C는 연구자의 질문에 적절한 대답을 하지 않으며 자신이 하고 싶어 하는 활동만 고집하는 경향을 보였다. 또한 아동 $\mathrm{A}, \mathrm{B}$ 와 마찬 가지로 간단한 지시 따르기는 가능하지만 '누구', ‘어디', '무엇'과 같 은 의문사 질문에 적절하게 반응하지 못하였으며, '안' '밖', ‘위'와 같은 위치부사어를 듣고 해당 위치에 물건을 가져다 놓는 활동에 오반응하였다. 그림을 보고 상황을 간단하게 2 개 이상의 적절한 문 장으로 설명하는 데도 어려움을 보였다.

연구대상의 언어검사 결과는 Table 1과 같다.

\section{연구도구}

본 연구의 연구도구는 증강현실 기반 언어중재로, 특히 동사 지 
도에 증강현실을 활용하는 것이므로 증강현실로 구현할 동사 목 록을 우선적으로 선정하였다. 동사 목록을 선정하기 위하여 한국 판 맥아더-베이츠 의사소통발달평가(Korean MacArthur-Bates Communicative Development Inventories, K M-B CDI; Pae \& Kwak, 2011) 유아용, 한국 아동의 어휘발달 연구(Choi, 2000), 등급별 국 어교육용 어휘(Kim, 2003), 3-6세 아동의 발달에 따른 동사 어휘 특성 및 빈도 연구(Cho, 2003), 3-8세 아동의 내용어 어휘발달 연구 (Choi, 2004), 영·유아 기초어휘선정 연구(Jang, Jeon, Shin, \& Kim, 2013)와Lee (1994)가 제시한 어휘선택 기준을 참고하여 100 개 동사 를 선정하였다. 이렇게 선정한 동사목록이 아동들에게 지도하기에 적절한 동사들인지에 대하여 Lee, Lee, Hwang, Kang과 Lee (2016) 는 타당도 연구를 진행하였다. 타당도는 어휘타당도와 모션(motion)타당도로 나누어 살펴보았는데, 어휘타당도는 언어치료학과 교수 3 명에게 이 동사목록이 아동들에게 지도하기에 적절한지 5점 Likert 척도를 사용하여 평가하게 하였고 이 결과 5점 만점에 평균 4.3으로 나타났다. 모션타당도는 증강현실로 구현되는 애니메이션 이 해당 동작을 정확하게 나타내는지를 살펴보는 것으로, 언어치료 전공 석사과정 학생들에게 증강현실로 구현된 애니메이션 모션을 보여주고 생각나는 동사를 기록하게 하였다. 그런 후 해당 동사와 모션일치도가 $50 \%$ 이상으로 응답된 동사목록을 언어치료전공 학 부 학생들에게 증강현실로 구현하여 보여주었다. 그리고 이들에게 해당 목표 동사와 증강현실 간의 일치도를 5점 척도(매우 일치하지

Table 1. Language abilities of the participants

\begin{tabular}{|c|c|c|c|c|c|}
\hline & \multirow{2}{*}{ Sex } & \multirow{2}{*}{$\begin{array}{c}\text { Age } \\
\text { (yr:mo) }\end{array}$} & \multicolumn{2}{|c|}{ Language age $\mathrm{e}^{\mathrm{a}}$ (yr;mo) } & \multirow{2}{*}{$\begin{array}{c}\text { Number of } \\
\text { expressive verbs }\end{array}$} \\
\hline & & & Receptive & Expressive & \\
\hline Subject $A$ & $\mathrm{~F}$ & $3 ; 10$ & $3 ; 8(26)$ & $3 ; 3(21)$ & 83 \\
\hline Subject B & M & $3 ; 9$ & $3 ; 7(25)$ & $3 ; 3(21)$ & 78 \\
\hline Subject C & $\mathrm{F}$ & $3 ; 0$ & 2;11 (17) & $2 ; 6(12)$ & 66 \\
\hline
\end{tabular}

The number in parentheses indicates raw score.

aPRES = Preschool Receptive-Expressive Language Scale (Kim, Sung, \& Lee, 2003). ${ }^{b} \mathrm{~K}$ M-B CDI=Korean MacArthur-Bates Communicative Development Inventories (Pae \& Kwak, 2011).
않음 ‘0’-매우 일치함 ‘5’)로 평가하게 하였다. 이를 통하여 5점 만점 에서 3 점 이상의 모션타당도 점수를 얻은 동사만을 목표동사로 포 함시켰다. 여기에 Hwang과 Lee (2017)가 증강현실로 구현한 동사 목록을 추가하여 최종 84 개의 동사를 본 연구의 증강현실 기반 언 어중재에 활용할 목표동사로 선정하였다. 각 동사가 사용될 가능 성이 높은 공간을 중심으로 장소를 거실, 방, 주방, 욕실로 나누어 목표동사목록을 Table 2에 제시하였다.

본 연구에서 활용한 증강현실 시스템은 카메라로 마커를 인식하 게 한 후 이 마커를 통하여 3차원 영상이 태블릿 PC에 보이도록 하 는 시스템이다. 이러한 기능을 구현하기 위하여 마커, $3 \mathrm{D}$ 모델, $3 \mathrm{D}$ 모델의 동작 애니메이션이 필요하므로 $3 \mathrm{D}$ 모델을 증강하기 위하여 Vuforia 라이브러리를 사용하였다. 그리고 Unity 3D 프로그램을 이용하여 애플리케이션으로 제작한 후 LG Gpad III 10.1 (2017)을 사용하여 증강으로 구현하였다. 본 연구에서 사용한 마커 및 목표 동사 어휘가 증강현실로 구현된 화면은 Figure 1과 같다.

마커를 책상 위에 두고 태블릿 PC의 카메라로 마커를 비추면 $\mathrm{PC}$ 의 화면 위로 훈련모드, 연습모드, 평가모드가 적혀진 첫 화면이 보인다. 연구자가 화면 위의 훈련모드를 터치하면 목표동사가 증강 현실로 구현될 장소(방, 거실, 욕실, 부엌)를 선택하라는 화면이 나 오게 된다. 거실을 터치하면 목표동사목록이 뜨고 치료사가 해당 되는 목표동사가 적힌 문자(예: 깎다[peel])를 터치하면 Figure 1에 서 보는 바와 같이 '엄마 캐릭터가 거실 소파에 앉아서 사과를 깎 는’ 애니메이션이 제시된다. 태블릿 PC의 카메라를 마커의 어느 위 치로 이동하느냐에 따라 엄마 캐릭터의 얼굴이 보이거나 사과를 깎 고 있는 동작을 더 크게 볼 수 있는 등 현실과 가상이 공존하는 증 강현실을 경험할 수 있도록 구성되어 있다. Figure 1에서 제시한 또 다른 동사인 '자르다(cut)'의 경우에는 아동의 생일축하파티에서 아빠와 아이 캐릭터가 지켜보는 가운데 엄마 캐릭터가 케이크를 잘 라주는 애니메이션이 증강현실로 구현되도록 하였다.

\section{연구절차}

증강현실 기반 언어중재의 효과를 살펴보기 위하여 연구 목적

Table 2. Lists of verbs for language intervention based on augmented reality

\begin{tabular}{|c|c|c|}
\hline Place & Number of verbs & Verbs \\
\hline Room & 24 & $\begin{array}{l}\text { tickle, dress, undress, hang, draw, paint, erase, turn on the light, put out, lie, cover, sleep, put, rise, hear, take out, take, write, hold, } \\
\text { color, get scolding, cry, hide, roll }\end{array}$ \\
\hline Living room & 47 & $\begin{array}{l}\text { peel, spear, take a picture, repair, insert, light a fire, sing, blow, clap one's hands, cut, devide, eat, enter, come out, shut, kiss, clean } \\
\text { up, watch, stand up, dance, sit, snap, knock, apply (medicine), throw out, hug, smile, put on, give, kick, call, roll, walk, run, tremble, } \\
\text { fight, jump, greet, lie down, throw, pick up, yawn, crawl, go up, go down, dangle, die }\end{array}$ \\
\hline Kitchen & 6 & break, drink, cook, suck, pour, spill \\
\hline Bathroom & 7 & wash up, brush one's teeth, wipe, take a dump, pump bilge, apply (lotion) \\
\hline
\end{tabular}




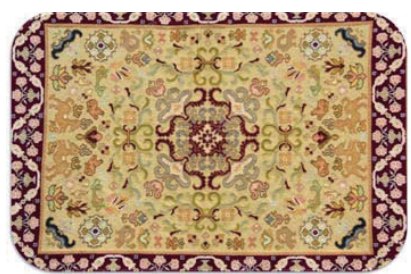

(A)

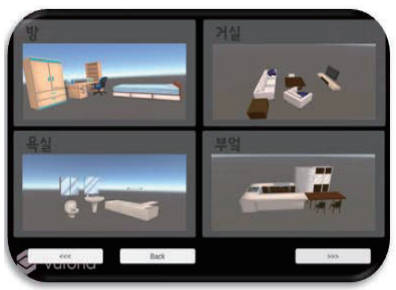

(C)

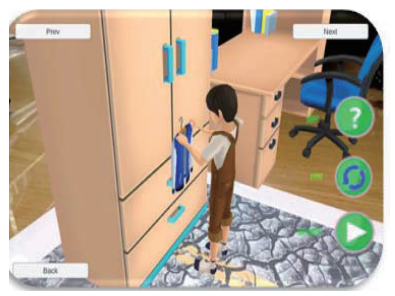

(E)

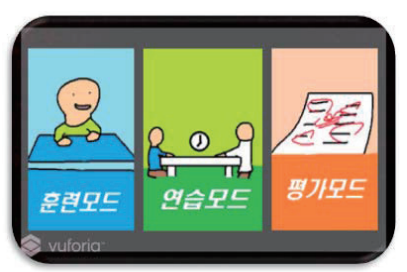

(B)

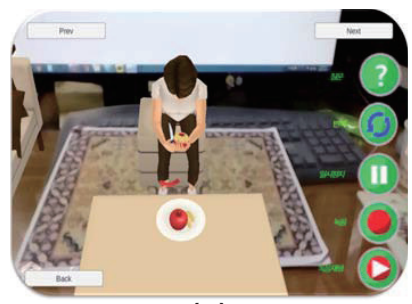

(D)

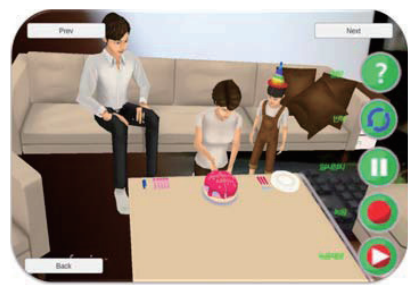

(F)
Figure 1. Examples of verbs based on augmented reality. (A) Maker, (B) first screen, (C) screen for selection of places, (D) peel, (E) hang, and (F) cut.

및 절차에 대한 내용을 호남대학교 생명윤리위원회 승인을 취득한 후(IRB No. 1041223-201702-HR0044) 연구를 진행하였다. 연구대 상 모집은 지역 내 온라인 육아카페에 연구내용을 공지한 후 자발 적인 참여의사를 보인 경우에 한하여 모집하였다. 선별검사를 통하 여 연구대상으로 선정된 아동들에게 증강현실 기반 언어중재의 효 과를 알아보기 위하여 중다기초선설계로 실험을 진행하였다. 매주 2 회기씩 진행하여 기초선, 중재, 유지 단계로 실시하였고 실험기간 은 2017년 7월 1 일부터 9 월 30 일까지로 아동에 따라 총 18 회기에서 23 회기를 실시하였다.

기초선 단계에서는 연구대상 3 명 모두 동일한 시기에 각 아동에 게 개별적으로 증강현실로 구현한 $3 \mathrm{D}$ 캐릭터의 동작 애니메이션을 보여주고 해당 동사를 표현할 수 있는지를 살펴보았다. 이 때 사용 한 동사목록은 목표동사 84 개 중 무작위로 추출한 것으로서 연구 자는 아동의 반응에 대하여 어떠한 피드백이나 강화도 제공하지 않았다. 중재 단계에서는 기초선에서 안정세를 보이는 아동에게 증 강현실 기반 언어중재를 제공하였다. 중재는 언어치료실 내에서 개 별적으로 수행되었으며 한 회기당 30 분 정도 소요되었고 회기별 7 개의 목표 동사가 제시되었다. 연구자는 태블릿 PC를 이용하여 $3 \mathrm{D}$ 애니메이션을 증강현실로 구현한 후 아동에게 “(친구가) 무엇을 하
고 있나요?"와 같이 질문을 하였다. 아동이 정반응할 경우에는 사 회적 강화를 제공하였고, 대답하지 못할 경우 첫음절 단서를 제공 하였다. 단서 제공에도 대답을 하지 못하면 해당 동사의 모델을 제 공하여 모방 발화하도록 유도하였다. 유지 단계는 중재 단계 종료 후 1 주일의 휴지기간이 지난 후 기초선과 동일한 조건에서 3 회기를 실시하여 중재효과가 유지되고 있는지 살펴보았다. 일반화 단계에 서는 아동의 가정에서 주양육자가 동사 그림카드를 제시하였을 때 에도 아동이 목표동사를 자발발화할 수 있는지를 살펴보았다.

\section{결과 처리}

목표동사를 제시하였을 때 아동이 정반응할 경우 증강현실 애 플리케이션에 결과를 (+)로, 오반응할 경우 (-)로 기록하였다. 결과 기록시, 연구대상 아동들의 연령을 고려하여 오조음과 같은 발달 적 오류는 정반응으로 간주하였으며 아동이 사용하는 어미에 상 관없이 어간을 정확하게 표현할 경우에는 정반응으로 간주하였다 (예: '먹다'의 경우 ‘먹었다', '먹어요', ‘먹는다', '먹었어요' 모두 정반 응으로 기록하였음). 정반응률에 대한 신뢰도를 측정하기 위하여 연구대상별 3회기씩 무선 표집하여 언어재활 석사과정의 대학원 생 2명이 각각 정반응을 분석한 결과 일치도는 $98.8 \%$ 로 나타났다. 결과는 각 회기별 정반응률(\%)로 제시하였는데, 즉 회기별 목표동 사목록 7개 중 아동이 자발 발화한 동사 수를 목표 동사목록 수인 7 로 나눈 후 100 을 곱하여 산출하였다(정반응률 = 정반응 동사 수/7×100).

\section{연구결과}

\section{동사 정반응률의 변화}

증강현실 기반 언어중재가 동사 표현에 미치는 효과를 알아보기 위하여 기초선, 중재, 유지 단계에서 각 아동들이 보이는 동사 표현 정반응률을 Figure 2에 제시하였다.

아동 $\mathrm{A}$ 의 경우, 기초선 단계에서 평균 $52.3 \%$ 의 정반응률을 보여 다른 아동들보다 기초선 단계의 점수가 높게 나타났다. 중재가 시 작되어서도 정반응률이 꾸준히 증가하여 평균 $83.3 \%$ 의 정반응률 을 보였다. 유지 단계에서의 정반응률이 $90.6 \%$ 로 나타나 증강현실 기반 언어중재 프로그램이 아동 $\mathrm{A}$ 의 동사 습득에 긍정적인 영향을 미친 것을 알 수 있었다. 아동 $\mathrm{A}$ 는 주의력 및 학습태도가 양호하였 고 증강현실 프로그램에 흥미를 가지고 스스로 태블릿 $\mathrm{PC}$ 를 조작 하려고 하는 등, 호기심을 보였다. 아동들의 동사 표현 총 개수를 살 펴보았을 때, 아동 $\mathrm{A}$ 는 목표동사 84 개 중 총 70 개 동사를 표현할 수 있는 것으로 나타났다. 


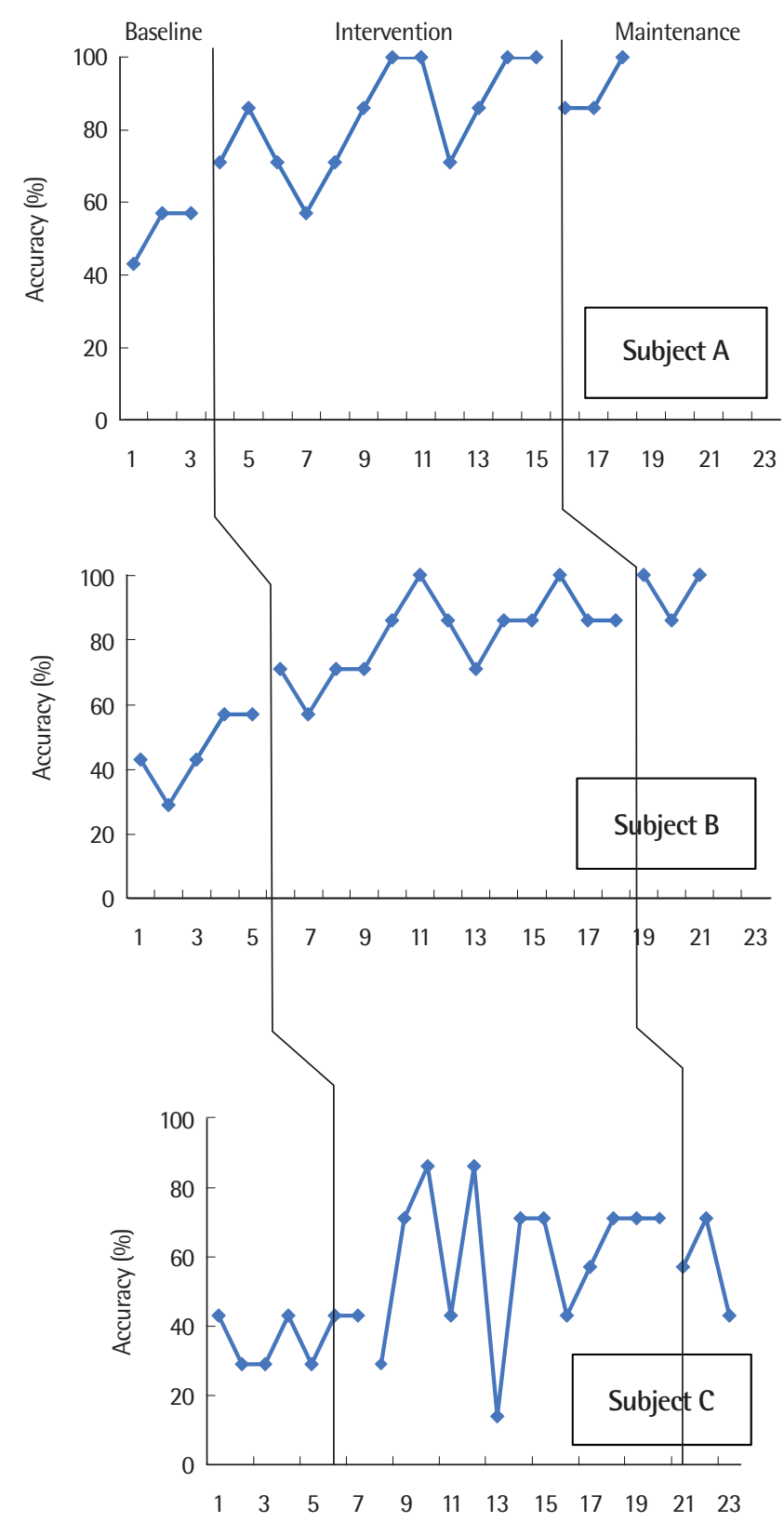

Figure 2. Accuracy of expressive verbs through language intervention based on augmented reality.

아동 B의 경우, 기초선 단계에서 평균 $45.8 \%$ 의 정반응률을 보였 으나 중재 단계에서는 평균 $80.9 \%$ 로 정반응률이 $35.1 \%$ 향상된 것 으로 나타났다. 연구대상 3 명 중 가장 높은 중재효과를 보인 아동 이었으며 유지 단계에서도 $95.3 \%$ 의 정반응률을 보여 증강현실 기 반 언어중재의 효과가 유지되고 있음을 알 수 있었다. 프로그램 진 행 시 연구자가 마커를 움직여 증강현실로 $3 \mathrm{D}$ 애니메이션을 구현 하자 아동 $\mathrm{B}$ 는 자신이 직접 움직여 보겠다며 중재 과정 전반에 매 우 적극적으로 참여하였다. 집중도 및 흥미도가 가장 높은 아동이
었으며 연구자와의 상호작용도 잘 이루어졌다. 아동들의 동사 표현 총 개수를 살펴보았을 때, 아동 $\mathrm{B}$ 는 목표동사 84 개 중 총 67 개의 동 사를 표현할 수 있는 것으로 나타났다.

아동 C는 기초선 단계 동안 평균 $38.4 \%$ 의 정반응률을 보였다. 중 재 단계는 평균 $60.3 \%$ 의 정반응률을 보여 향상률이 $21.9 \%$ 로 나타 났다. 유지 단계에서는 평균 $57 \%$ 의 정반응률을 보여 중재 효과가 유지되는 것으로 나타났으며 아동 $\mathrm{A}, \mathrm{B}$ 와 비교하였을 때 상대적으 로 향상도가 낮은 편이었다. 아동 C의 경우 중재 초기에는 호기심 을 보이며 프로그램에 흥미를 보였으나 주의 집중에 어려움을 보였 고 소극적인 성향으로 반응도가 낮게 나타났다. 아동들의 동사 표 현 총 개수를 살펴보았을 때, 아동 $\mathrm{C}$ 는 목표동사 84 개 중 총 50 개의 동사를 표현할 수 있는 것으로 나타났다.

\section{증강현실 기반 언어중재의 일반화}

증강현실 기반 언어중재의 일반화를 알아보기 위하여 치료실이 아닌 아동의 가정에서, 치료사가 아닌 아동의 어머니가, 태블릿 PC 를 활용하여 증강현실로 구현하지 않고 그림카드로 제시하였을 때 아동이 해당 목표동사를 정반응하는지 살펴보았다. 일반화 단계에 서 84 개 목표동사 중 무선 표집한 40 개 동사를 아동들에게 제시하 여 일반화를 확인하였다.

아동 $\mathrm{A}$ 와 $\mathrm{B}$ 는 제시된 동사 그림카드 40 개 모두에 대하여 정확히 해당 동사를 말하여 $100 \%$ 정반응률을 보였고 아동 C는 $62.5 \%$ 의 정반응률을 보였다 이를 통하여 증강현실 기반 언어중재가 동사 표현에 있어서 자극일반화를 보이는 것을 알 수 있었다.

\section{논의 및 결론}

본 연구의 목적은 증강현실 기반 언어중재가 표현언어발달지연 아동의 동사 표현 향상에 기여하는지 그 효과를 밝히는 것이다. 연 구대상은 생활연령 평균이 3세 6개월이며 표현언어능력이 생활연 령에 비하여 지체된 아동 3 명으로, 선행연구의 기초어휘 선정방식 을 참고하여 목표동사 84 개를 선정하고 이를 증강현실로 구현한 $3 \mathrm{D}$ 동작 애니메이션을 활용하여 증강현실 언어중재를 실시하였다. 본 연구를 통하여 얻은 결과는 다음과 같다.

첫째, 증강현실 기반 언어중재는 표현언어발달지연 아동의 동사 표현에 효과적인 것을 알 수 있었다. 중재 단계에서의 정반응률을 아동별로 살펴보면 아동 $\mathrm{A}$ 는 $83.3 \%$, 아동 B는 $80.9 \%$, 아동 C는 $60.3 \%$ 로 기초선 단계에 비하여 중재 단계에서 정반응률 평균이 $29.3 \%$ 상승된 것으로 나타났다. 회기가 진행될수록 정반응률이 높 아졌지만 연구대상 아동들이 표현에 어려움을 보였던 동사 목록들 
은 ‘(포크로) 찍다', ‘(약) 바르다', '혼나다', '붓다', '끊어지다' 등이었 다. 중재 단계에서 보였던 높은 정반응률은 중재 종료 이후에도 유 지되는 것으로 나타났다.

둘째, 증강현실 기반 언어중재는 표현언어발달지연 아동의 동사 표현 일반화에 효과적인 것을 알 수 있었다. 가정에서 아동의 어머 니가 동사카드를 제시하여 질문하였을 때에도 연구대상 아동 모두 목표동사들에 대하여 높은 정반응률을 보였다. 이를 통하여 증강 현실 기반 언어중재를 통하여 학습한 동사는 다른 자극 및 상황으 로도 일반화되므로 표현언어발달지체 아동들의 동사 표현 향상에 효과적인 방법인 것으로 확인할 수 있었다.

이러한 연구결과는 지적장애 아동을 대상으로 증강현실 기반 언 어치료 프로그램을 적용하여 동사 산출에서 긍정적인 효과를 보 고한 Ahn, Bae, Park과 Kwon (2017)의 연구 결과와 Kim, Park과 $\operatorname{Kim}$ (2005), Jo (2012)가 밝힌 바와 같이 동적 움직임이 동사 학습 에 효과적이었다는 연구결과와도 그 맥락을 같이 하고 있다. 이를 통하여 언어중재 시 움직임이 포함된 자극을 증강으로 제시하는 경우 동사 습득에 도움이 됨을 알 수 있다. 증강현실 기반 언어교육 프로그램을 학습장애 학생들에게 적용하여 언어능력과 학습태도 향상에 효과적이었음을 밝힌 Lee와 Ryu (2014)의 연구, 증강현실 기반 언어치료 프로그램을 실어증 환자에게 적용하여 이름대기 및 의사소통 기능 향상에 긍정적인 영향을 보였다고 보고한 Ahn 등 (2017)의 연구에서처럼 증강현실을 언어치료에 활용하는 것은 동 사 표현뿐만 아니라 다양한 언어능력에 영향을 미친다.

증강현실을 활용한 중재는 아동의 흥미를 유발하고 동기를 높임 으로써 아동으로 하여금 언어치료에 보다 적극적이고 활발히 참여 하게 하는 훌륭한 계기가 될 것이다. 가상과 현실이 공존하는 증강 현실에서 아동은 수동적인 존재라기보다는 직접 조작을 할 수 있 고 경험 중심의 학습 및 치료가 가능해질 것이다. 따라서 아동의 능 동적인 반응을 유도하게 됨에 따라 치료에 긍정적인 영향을 미치게 될 것이다. 본 연구결과 및 선행연구 결과를 바탕으로 동사 학습 시 에는 움직임이나 변화를 나타내줄 수 있는 증강현실과 같은 자극 제공방법이 도움이 될 수 있을 것으로 판단된다. 이러한 연구결과 를 바탕으로 표현언어발달지연 아동의 언어능력 평가 및 중재 시 제공하는 자극 유형으로 증강현실 활용을 고려해보는 등, 다차원 적인 접근이 필요할 것으로 보인다.

증강현실 기반 언어중재는 자극일반화에도 효과적인 것으로 나 타났는데, Kim 등(2005)도 언어장애 아동에게 언어중재 소프트웨 어를 활용하여 선 그림으로 자극일반화에 효과를 보고하였다. Kye 와 $\operatorname{Kim}(2008)$ 또한 증강현실 활용 프로그램이 일반 맥락 적용에 도 의미가 있음을 밝혔다. 본 연구의 결과와 이러한 선행연구들 모
두 증강현실을 통한 학습내용은 일반화에도 용이하다는 것을 보 고하였으며 이를 통하여 증강현실 기반 언어중재가 동사 학습에 유용한 방법이라 볼수 있을 것이다.

결론적으로 표현언어발달이 느린 아동들에게 동사를 학습시키 기 위하여 증강현실을 활용하여 언어중재를 제공한 것은 동사 표 현에 효과적이며 일반화에도 효과적이었으므로 임상에서 적용하 기에 유용성이 있다고 할 것이다. 그러나 본 연구는 몇 가지 제한점 을 가지고 있으므로 이를 통하여 후속연구에서에 대한 제언을 하 면 다음과 같다. 첫째, 본 연구에서 사용한 증강현실 기반 언어중재 는 증강현실을 구현할 수 있는 플랫폼이 안드로이드 기반에 한정적 이므로 향후 다양한 플랫폼에서 호환 가능한 버전을 개발하는 것 이 임상에서의 활용도를 높일 수 있을 것이다. 둘째, 증강현실로 구 현한 몇몇 동사는 동작의 정확도가 다소 낮은 편이라 아동들이 인 지하기에 어려움이 있었다. 예를 들어 '포크로) 찍다’의 경우 화면 속 $3 \mathrm{D}$ 캐릭터가 포크로 과일을 찍는 동작에서 멈추어야 하는데 찍 은 후 입 가까이에 가져가는 동작까지 제공됨으로써 아동들이 "먹 어요”로 대답하는 경우가 많았다. 본 연구 실시 전 어휘목록의 타 당도 연구는 진행하였으나(Hwang, Kwon, Kim, \& Shin, 2017), 전 형적인 언어발달을 보이고 있는 아동들을 대상으로 한 동작 타당 도 연구는 실시하지 못하였다. 향후 $3 \mathrm{D}$ 캐릭터가 나타내는 동작이 아동들이 보았을 때 목표 동사로 보이는지에 대한 타당도 연구를 진행할 필요가 있을 것이다. 셋째, 본 연구에서 증강현실로 구현한 동사들은 발달 초기에 습득되는 동사들이었으므로, 연구대상 $\mathrm{A}$ 와 $\mathrm{B}$ 의 경우에는 이미 기초선 단계에서부터 이 동사들 중 절반에 가까 운 동사를 표현할 수 있었다(예: 노래하다, 박수치다, 먹다, 끄다, 그 리다 등). 사전 평가에서 연구대상 아동들이 이미 표현하고 있는 어 휘들을 목표어휘에서 배제하였어야 하나, 증강현실로 구현할 수 있 는 동사목록이 84 개로 많지 않아 그 목록을 그대로 중재에 활용한 것은 본 연구의 제한점이라 하겠다. 향후 증강현실로 구현할 수 있 는 동사목록이 더욱 많아지고 기술적인 문제가 개선되길 기대하며 후속 연구에서는 어휘 목록에 대한 사전 평가를 정확히 실시할 필 요가 있다. 넷째, 본 연구에서는 중재 단계 후 일주일의 휴지기간을 지나 중재효과의 유지를 측정하였으나 중재 이후의 시간적 간격이 지나치게 짧으므로 유지효과로 보기에 다소 무리가 따른다. 추후 연구에서는 최소 3 주 정도의 기간을 둔 후 유지를 측정하는 것이 바람직할 것으로 보인다. 다섯째, 본 연구는 증강현실을 표현언어발 달지연 아동의 동사 습득에 제한적으로 살펴보았지만 향후 연구에 서는 다양한 의사소통장애군에게 적용해볼 수 있을 것이며 다양 한 언어 영역에 대한 수용 및 표현능력에 미치는 효과에 대하여 살 펴볼수 있기를 기대한다. 


\section{REFERENCES}

Ahn, B. K., Bae, I. H., Park, H. J., \& Kwon, S. B. (2017). Effect of verb word using improvement in speech therapy program on based augmented reality of children with intellectual disability. Proceedings of the 5th collaboration on Korean Speech-Language and Hearing Association.Korean Academy of Speech-Language Pathology and Audiology, Busan, Korea.

Bae, I. H., Park, H. J., Kim, K. H., \& Kwon, S. B. (2014). Educational application of speech therapy program based on augmented reality. Journal of Speech \& Hearing Disorders, 23, 139-152.

Billinghurst, M., \& Kato, H. (2002). Collaborative augmented reality. Communications of the ACM, 45, 64-70.

Caselli, M. C., Bates, E., Casadio, P., Fenson, J., Fenson, L., Sanderl, L., \& Weir, J. (1995). A cross-linguistic study of early lexical development. Cognitive Development, 10, 159-199.

Cho, J. S. (2003). A study for children's frequencies and characteristics in verbal vocabulary aged from 3 to 6 (Master's thesis). Korea Nazarene University, Cheonan, Korea.

Choi, E. A. (2004) Development of Korean children's vocabulary: 3 to 8 years children oriented (Master's thesis). Korea Nazarene University, Cheonan, Korea.

Choi, E. H. (2000). A study of vocabulary development of Korean children (Master's thesis). Yonsei University, Seoul, Korea.

Genter, D. (1982). Why nouns are learned before verbs: linguistic relativity versus natural partitioning. In S. A. Kuczaj (Ed.), Language development: syntax and semantics (pp. 125-158). Hillsdale, NJ: Erlbaum.

Hwang, B. M., \& Lee, M. J. (2017). Development of augmeted reality model for evaluating children's language ability. Proceedings of the 2017 spring conference on The Korean Society of Speech Sciences, Cheonan, Korea.

Hwang, B. M., Kwon, S. B., Kim, S. J., \& Shin, B. J. (2017). A basic study of verbs list for vocabulary learning based on augmented reality. Journal of Rehabilitation Research, 21, 233-246.

Jang, S. H., \& Kye, B. K. (2007). Augmented reality applications in education. Journal of Korea Contents Association, 5, 79-85.

Jang, H. J., Jeon, H. S., Shin, M. S., \& Kim, H. J., (2013). A study on selection of basic vocabulary for infants and toddlers. Journal of Speech \& Hearing Disorders, 22, 169-187.

Jo, M. K. (2012). Language intervention using internet animated fairy tale story for children with intellectual disabilities the effect of story comprehension and syntax understanding (Master's thesis). Daegu University, Gyeongsan,
Korea.

Kang, D. H., Park, H. J., Song, B. D., Kim, J. D., \& Shin, B. J. (2015). Design and development of an articulation and phonological disorder assessment system using augmented reality. Journal of Speech \& Hearing Disorders, 24, 87-94.

Kim, K. (2003). Vocabularies for different levels of Korean education. Seoul: Pagijung.

Kim, Y. G., \& Kwon, S. B., (2017). Trends analysis of augmented reality technology applied in special education. Journal of Special Education \& Rehabilitation Science, 56, 127-146.

Kim, Y. T., Lee, J. Y., Hong, G. H., Kim, K. H., \& Chang, H. S. (2009). Validity of the receptive and expressive vocabulary test on preschool children with language delay. Journal of Speech-Language \& Hearing Disorders, 18, 57-72.

Kim, Y. T., Park, S. H., \& Kim, Y. R. (2005). The effect of CAI on the verb expression and the number of complex sentences. Korean Journal of Communication \& Disorders, 10, 61-79.

Kim, Y. T., Sung, T. J., \& Lee, Y. K. (2003). Preschool receptive-expressive language scale (PRES). Seoul: Seoul Community Rehabilitation Center.

Kye, B. K., \& Kim, Y. S. (2008). Investigation on the relationships among media characteristics, presence, flow, and learning effects in augmented reality based learning. Journal of Educational Technology, 24, 193-224.

Lee, C. (1994). Key-words selection for Korean vocabulary teaching. Korean Language Education, 85, 19-39.

Lee, K. (2011). Present and future of augmented reality skill. TTA Journal, 133, 88-93.

Lee, M. K., Lee, M. J., Hwang, B. M., Kang, D. H., \& Lee, S. J. (2016). Validity for verbs list of communication system based on augmented reality. Proceedings of International Conference on Korean Speech-Language \& Hearing Association, 173-176.

Lee, T., \& Ryu, J. (2014). The effects of augment reality based language intervention program on language abilities and learning aptitudes of students with learning disabilities. The Korea Journal of Learning Disabilities, 11, 31-52.

Nash, M., \& Donaldson, M. L. (2005). Word learning in children with vocabulary deficits. Journal of Speech, Language, and Hearing Research, 48, 439458.

Pae, S., \& Kwak, K. C. (2011). Korean MacArthur-Bates Communicative Development Inventories (KM-B CDI). Seoul: Mindpress.

Ryu, J., Jo, I. H., Heo, H. O., Kim, J. H., \& Kye, B. K. (2006). The next generation of learning for augmented reality enhanced in tangible interface. Daegu: 
Korea Education and Research Information Service.

Shim, H. Y., Cho, S. H., \& Kim, H. J. (2017). Development and effect of convergence talent education program based on the augmented reality (AR) for the 4th Industrial Revolution. Journal of Cultural Industry Studies, 17, 119-127.

Tomasello, M. (1992). First verbs: a case study of early grammatical development. Cambridge: Cambridge University Press.

Tomasello, M., \& Kruger, A. C. (1992). Joint attention on actions: acquiring verbs in ostensive and non-ostensive contexts. Journal of Child Language, $19,311-333$

Waxman, S. R., \& Lidz, J. L. (2006). Early word learning. In Handbook of child psychology: Volume 2 cognition, perception, and language (6th ed., pp. 299335). Hoboken, NJ: John Wiley \& Sons.

Weizman, Z. O., \& Snow, C. E. (2001). Lexical output as related to children's vocabulary acquisition: effects of sophisticated exposure and support for meaning. Developmental Psychology, 37, 265-279. 


\section{국문초록}

\section{증강현실 기반 언어중재가 표현언어발달지연 아동의 동사 표현에 미치는 효과 이명진 ${ }^{1}$ 황보명}

${ }^{1}$ 호남대학교 대학원 재활과학과 언어치료전공, ${ }^{2}$ 호남대학교 보건과학대학 언어치료학과

배경 및 목적: 언어발달이 느린 아동들은 어휘 습득 시 행동이나 상태 변화를 나타내는 동사 학습에 어려움을 보인다. 본 연구에서는 동사 학습의 용이성을 증대하기 위하여 표현언어발달지연아동에게 현실 환경에서 동작을 직접 보여주는 증강현실 기반 언어중재를 제 공하여 동사 표현 정반응률과 일반화에 미치는 영향을 살펴보았다. 방법: 생활연령에 비하여 표현언어가 지연된 아동 3 명(생활연령 평 균 3 세 6 개월)에게 총 84 개의 동사를 증강현실로 구현한 증강현실 기반 언어중재를 실시하였다. 대상자 간 중다기초선설계를 이용하여 기초선, 중재, 유지 단계에서 7 개씩의 목표동사를 증강현실로 구현하여 동사 표현 정반응률을 살펴보았다. 또한 일반화를 알아보기 위 하여 목표동사를 그림카드로 주양육자가 제시하였을 때에도 정반응하는지 살펴보았다. 결과: 연구대상 모두 기초선 단계에 비하여 중 재 단계와 유지 단계에서 정반응률이 증가하였으며 치료실 이외의 장소에서 그림카드로 제시하였을 때에도 일반화하여 목표동사를 발 화할 수 있는 것으로 나타났다. 논의 및 결론: 증강현실 기반 언어중재는 표현언어발달지연 아동의 동사 표현을 증가시키는 데 효과적 이며 다양한 장애군에도 적용할수 있을 것으로 기대된다.

핵심어: 증강현실, 표현언어발달지연, 아동, 동사

본 논문은 2015년 대한민국 교육부와한국연구재단의 지원을 받아 수행되었음(No. 2015S1A5B6037281).

본 논문은 제 1 저자의 석사학위 논문을 수정보완한 것임.

\section{참고문헌}

강덕훈, 박희준, 송복득, 김진동, 신범주 (2015). 증강현실을 이용한 조음음운장애 검사 시스템 설계 및 구현. 언어치료연구, 24, 87-94.

계보경, 김영수 (2008). 증강현실 기반 학습에서 매체특성, 현존감, 학습몰입, 학습효과의 관계 규명. 교육공학연구, 24, 193-224.

김광해(2003). 등급별 국어교육용 어휘. 서울: 박이정.

김영태, 박소현, 김영란(2005). 보조적인 언어훈련 소프트웨어의 활용이 언어발달지체 아동의 동사표현 및 복문의 습득에 미치는 효과. 언어청각장애

연구, 10, 61-79.

김영태, 성태제, 이윤경(2003). 취학전 아동의 수용언어 및 표현언어 척도(PRES). 서울: 서울장애인종합복지관.

김영태, 이주연, 홍경훈, 김경희, 장혜성(2009). 수용-표현 어휘력검사(Receptive Expressive Vocabulary Test)의 타당도 연구: 취학 전 언어발달지체 아동을 중심으로. 언어치료연구, $18,57-72$.

김유경, 권순복(2017). 특수교육에 적용된 증강현실 기술의 국내외 연구동향 분석. 특수교육재활과학연구, 56, 127-146.

류지헌, 조일현, 허희옥, 김정현, 계보경(2006). 증강현실 기반차세대체험형 학습모형 연구. 대구: 한국교육학술정보원.

배소영, 곽금주(2011). 한국판 맥아더-베이츠 의사소통발달평가(K M-B CDI). 서울: 마인드프레스.

배인호, 박희준, 김근효, 권순복(2014). 증강현실 기반 언어치료 프로그램의 교육적 적용. 언어치료연구, 23, 139-152.

심효영, 조성화, 김효정 (2017). 4차 산업혁명을 대비한 증강현실(AR)기반의 융합인재교육 프로그램 개발 및 효과. 문화산업연구, 17, 119-127.

안병강, 배인호, 박희준, 권순복 (2017). 증강현실기반 언어치료 프로그램이 지적장애아동 동사 사용 향상에 미치는 효과. 제 5 회 한국언어치료학회.

한국언어청각임상학회 공동학술대회.

이건(2011). 증강현실 기술의 현재와 미래. 한국정보통신기술협회지, 133, 88-93.

이미경, 이명진, 황보명, 강덕훈, 이성진(2016). 증강현실 기반 의사소통 시스템 동사목록의 타당도 연구. 한국언어치료학회 국제학술대회 발표논문

집, 173-176. 
이충우(1994). 한국어 어휘 교육을 위한 대표 어휘 선정. 국어교육, 85, 19-39.

이태수, 류재연(2014). 증강현실 기반 언어교육 프로그램이 학습장애 학생의 언어능력 및 학습태도에 미치는 영향. 학습장애연구, 11,31-52.

장상현, 계보경 (2007). 증강현실 콘텐츠의 교육적 적용. 한국콘텐츠학회지, 5, 79-85.

장현진, 전희숙, 신명선, 김효정(2013). 영·유아의 기초 어휘 선정 연구. 언어치료연구, 22, 169-187.

조미경(2012). 인터넷 애니메이션 동화를 활용한 언어중재가 지적장애아동의 이야기이해력 및 구문이해력에 미치는 효과. 대구대학교 대학원 석사학

위논문.

조진숙(2003). 3세에서 6세 아동의 발달에 따른 동사어휘특성 및 빈도연구. 나사렛대학교 대학원 석사학위논문.

최은아(2004). 3세에서 8세 아동의 내용어 어휘 발달 연구. 나사렛대학교 대학원 석사학위논문.

최은희(2000). 한국 아동의 어휘 발달 연구: 13-30개월 아동을 대상으로. 연세대학교 대학원 석사학위 논문.

황보명, 권순복, 김선종, 신범주(2017). 증강현실 기반 어휘 지도에서 동사 목록에 대한 기초 연구. 재활복지, 21, 233-246.

황보명, 이명진(2017). 아동 언어능력 평가를 위한 증강현실 활용 모델 개발. 2017 한국음성학회 봄 학술대회 발표논문집. 